Abstracta Iranica

Revue bibliographique pour le domaine irano-aryen

Volume 37-38-39 | 2018

Comptes rendus des publications de 2014-2016

\title{
Jonathan Stökl, Caroline Waerzeggers (eds.). Exile and Return. The Babylonian Context
}

\section{Astrid Nunn}

\section{(2) OpenEdition}

1 Journals

\section{Édition électronique}

URL : http://journals.openedition.org/abstractairanica/45402

DOI : 10.4000/abstractairanica.45402

ISBN : 1961-960X

ISSN : 1961-960X

Éditeur :

CNRS (UMR 7528 Mondes iraniens et indiens), Éditions de l'IFRI

Référence électronique

Astrid Nunn, « Jonathan Stökl, Caroline Waerzeggers (eds.). Exile and Return. The Babylonian Context », Abstracta Iranica [En ligne], Volume 37-38-39 | 2018, document 40, mis en ligne le 30 décembre 2018, consulté le 28 septembre 2020. URL : http://journals.openedition.org/abstractairanica/45402 ; DOI : https://doi.org/10.4000/abstractairanica.45402

Ce document a été généré automatiquement le 28 septembre 2020

Tous droits réservés 


\title{
Jonathan Stökl, Caroline Waerzeggers (eds.). Exile and Return. The Babylonian Context
}

\author{
Astrid Nunn
}

\section{RÉFÉRENCE}

Jonathan Stökl, Caroline Waerzeggers (eds.). Exile and Return. The Babylonian Context. Berlin: de Gruyter, 2015, VI+371 p. (Beihefte zur Zeitschrift für die alttestamentliche Wissenschaft 478) ISBN: 978-3-11-041928-3

1 De multiples études analysent l'exil forcé des Juifs en Babylonie après la conquête de Nabuchodonosor. Cette nouvelle publication se veut multidisciplinaire en combinant les études de théologiens, d'assyriologues et d'historiens. Elle se veut également innovatrice en contextualisant Babylone au sein de cet exil babylonien. Ainsi les sources cunéiformes jouent-elles un rôle important. Quatre articles de ce volume remarquable sont recensés dans ce numéro d'Abstracta iranica (Gauthier Tolini, Ran Zadok, Johannes Hackl \& Michael Jursa, Caroline Waerzeggers).

\section{AUTEURS}

ASTRID NUNN

Université de Munich 